\title{
When a Water Problem Is More Than a Water Problem: Fragmentation, Framing, and the Case of Agricultural Wetland Drainage
}

\author{
Sarah-Patricia W. Breen ${ }^{1 *}$, Philip A. Loring ${ }^{2}$ and Helen Baulch ${ }^{1}$ \\ ${ }^{1}$ Global Institute for Water Security, University of Saskatchewan, School of Environment and Sustainability, Saskatoon, SK, \\ Canada, ${ }^{2}$ Department of Geography, Environment, and Geomatics and the Arrell Food Institute, University of Guelph, \\ Guelph, ON, Canada
}

Complex interactions between water, society, the economy, and the environment necessitate attention to how water issues are framed, and the limitations of a water-centric framework for analyzing or solving problems. We explore this complexity through an example of an existing complex, or wicked, policy problem-the case of agricultural wetland drainage in the Canadian Prairies. Agricultural wetland drainage expands the amount of productive agricultural land, increasing agricultural efficiency

OPEN ACCESS

Edited by:

Anik Bhaduri,

Griffith University, Australia

Reviewed by:

Luiz Ubiratan Hepp,

Universidade Regional Integrada do Alto Uruguai e das Missões, Brazil

Teresa Ferreira,

Universidade de Lisboa, Portugal

*Correspondence:

Sarah-Patricia W. Breen

sarah.breen@usask.ca

Specialty section:

This article was submitted to

Freshwater Science,

a section of the journal

Frontiers in Environmental Science

Received: 10 August 2018 Accepted: 10 October 2018 Published: 30 October 2018

Citation:

Breen S-PW, Loring PA and Baulch H (2018) When a Water Problem Is More

Than a Water Problem:

Fragmentation, Framing, and the Case of Agricultural Wetland Drainage.

Front. Environ. Sci. 6:129

doi: 10.3389/fenvs.2018.00129 and productivity. Drainage is also one of the primary drivers of the loss of Canada's wetlands and is a hotly contentious issue between actors with divergent views and values in the Canadian Prairies. Using the nuances of drainage as an exemplar, we discuss how fragmented framings of water foster perspectives and solutions that fail to consider the full range of aspects and interactions, and contribute to the enduring conflicts that accompany drainage debates in many regions. First, we discuss agricultural wetland drainage as practiced in the province of Saskatchewan, where significant regulatory and governance changes are in progress. Next, we discuss the challenges of policy and governance fragmentation, both specific to water and to the surrounding system. Finally, we note potential alternative framings that, while specific to prairie water governance, provide guidance for how other complex social-ecological challenges might be approached.

Keywords: water governance, agricultural wetland drainage, fragmentation, water policy, framing

\section{INTRODUCTION}

The role of water in modern societies is both tremendous and tremendously complex. Water is widely recognized as a basic right; it is essential to human health and well-being, and not only for drinking and sanitation, but for food and energy production, as well as other economic activities (United Nations, 2003). Water is also essential to all components of the biosphere, meaning that when we alter the course, quantity, or quality of water through anthropocentric activities, there are serious consequences for countless species and ecosystems. Finally, water is at the center of multiple current events, such as the dramatic water shortage facing South Africa or catastrophic flooding in parts of Canada, which highlight the interconnectedness of water with challenges such as population growth and climate change. 
Given the multiple interactions between water, society, the economy, and the environment, some argue that approaching issues that involve water from a water-centric frame is inadequate for finding sustainable and equitable solutions (de Loë, 2017; de Loë and Patterson, 2017). Rather than focusing on water, per se, they argue that management and conservation need to instead "shift attention to the ways in which water matters to [various] actors and sectors" (de Loë, 2017, p. 231), such as the nexus of energy, food, and human health (Beck and Villarroel Walker, 2013; Loring et al., 2013). In this paper, we explore this proposition using the case of agricultural wetland drainage in the Canadian Prairies. It is important to note these limitations of water-centric framing are not specific to the Canadian Prairies, but can be seen in examples from around the world, in cases of water scarcity e.g., irrigation management in New Mexico; Cox, 2014 and South Africa Backeberg and Sanewe, 2006 and excess (e.g., flooding and floodplain management along the Danube and other European rivers ; European Environment Agency, 2018). That being said, the Canadian example has key features that we argue are useful for finding a direction forward.

Agricultural wetland drainage (drainage), the process of draining surface water from the landscape, expands the amount of land available to agriculture, with goals of increasing agricultural efficiency and productivity and benefiting producers and consumers alike (Wheater et al., 2013; Weber and Cutlac, 2017). Drainage is widespread in Canada, the world's fifth largest exporter of agriculture and agri-food products (Agriculture and Agri-Food Canada, 2016). With climate change, demand on Canadian agriculture is only expected to increase, and conflicts over drainage, expecially in the Prairie Provinces (i.e., Alberta, Saskatchewan, Manitoba), are likewise increasing. This is because while agricultural wetland drainage expands productive lands, increasing productivity and value, it is also one of the primary drivers of the loss of Canada's wetlands, including over half of the prairie potholes in Western Canada (Wheater et al., 2013; Weber and Cutlac, 2017). Groups such as agricultural producers, municipalities, and conservation organizations, as well as provincial and federal governments and First Nations, hold divergent views and values about drainage, in terms of the most desirable approaches, outcomes, and related policies for wetlands and land use.

Using the nuances of drainage in the Canadian Prairies as an exemplar, we discuss below how fragmented framings of water foster perspectives and solutions that fail to consider the full range of aspects and interactions. As such, we show how these limited framings can contribute to the enduring conflicts that accompany drainage debates in many regions. First, we provide an overview of agricultural wetland drainage in the province of Saskatchewan, where drainage, and conflict over drainage are extensive, and where significant regulatory and governance changes are ongoing. Next, we discuss the challenges of conceptual fragmentation, both specific to water and to the surrounding social-ecological system. We then discuss potential alternative frames that, while specific to prairie water governance, provide guidance for how other complex water and other social-ecological challenges might be approached.

\section{BACKGROUND}

Agricultural wetland drainage is the management of water through engineered means, like ditching and diversions, for the purposes of moving or eliminating water from the landscape (Wheater et al., 2013; Water Security Agency, 2016). There is a lengthy tradition of drainage across agricultural landscapes for the purpose of increasing the amount of productive land, allowing earlier spring seeding, improving soil conditions, and, more recently, facilitating use of new technology (e.g., large machinery with limited turning radius; Wheater et al., 2013; Weber and Cutlac, 2017). For producers, incentives like increased profit or increased land value, whether real, or perceived act as economic drivers of drainage.

Despite the obvious economic benefits to the agricultural sector, drainage also has negative impacts, with the loss of wetlands being perhaps the most apparent. Wetlands provide habitat as well as ecosystem services, including flood control (Bartzen et al., 2010). Wetland loss, change in watershed storage capacity, and associated changes in the pattern, speed, and volume of water moved across the landscape all have impacts on surface and ground water quality and quantity (Wheater et al., 2013). In addition to modifying landscape hydrology, drainage can accelerate the movement and discharge of nutrients and contaminants into downstream water bodies, creating both environmental and human health challenges (Blann et al., 2009; Bartzen et al., 2010; Weber and Cutlac, 2017). Such impacts, from habitat loss to a failure to accommodate a changing climate, are not currently captured within the current system for managing drainage or valuing, economically, the costs and benefits of the practice. For example, un-drained land generally has a lower assessed tax value in the province of Saskatchewan compared to drained land that could be cultivated.

The cumulative impacts of drainage are difficult to measure, given the complex structure of watersheds and the interaction of hydrological impacts of drainage with other factors like wet and dry climatic cycles, and the impacts of a changing climate (Schindler, 2001; Dumanski et al., 2015). As such the attribution of drainage impacts is challenging, as are determining cumulative impacts. For example, drainage approvals in Saskatchewan have been found to only consider local impacts, as opposed to watershed scale or cumulative impacts (e.g., downstream flooding; Ferguson, 2018). Land owners and operators have multiple economic incentives to drain land and few, if any, to not, despite negative impacts. This creates a "divergence between social and private interests," where private economic gains result in a loss of ecological services to society (Cortus et al., 2011).

Drainage has all of the makings of a "wicked problem"a governance challenge that involves multiple sets of values, has no definitive formulation or single solution, can cross scales and boundaries, and involves circumstances that are unique from place to place (Rittel and Webber, 1973). Drainage involves common pool resources, specifically water, and affects shared ecosystem services, but the activity of drainage is not specifically harvesting those resources or services (see Figure 1). Depending on one's perspective, drainage can be seen as a process of land improvement driven by pressure to increase 


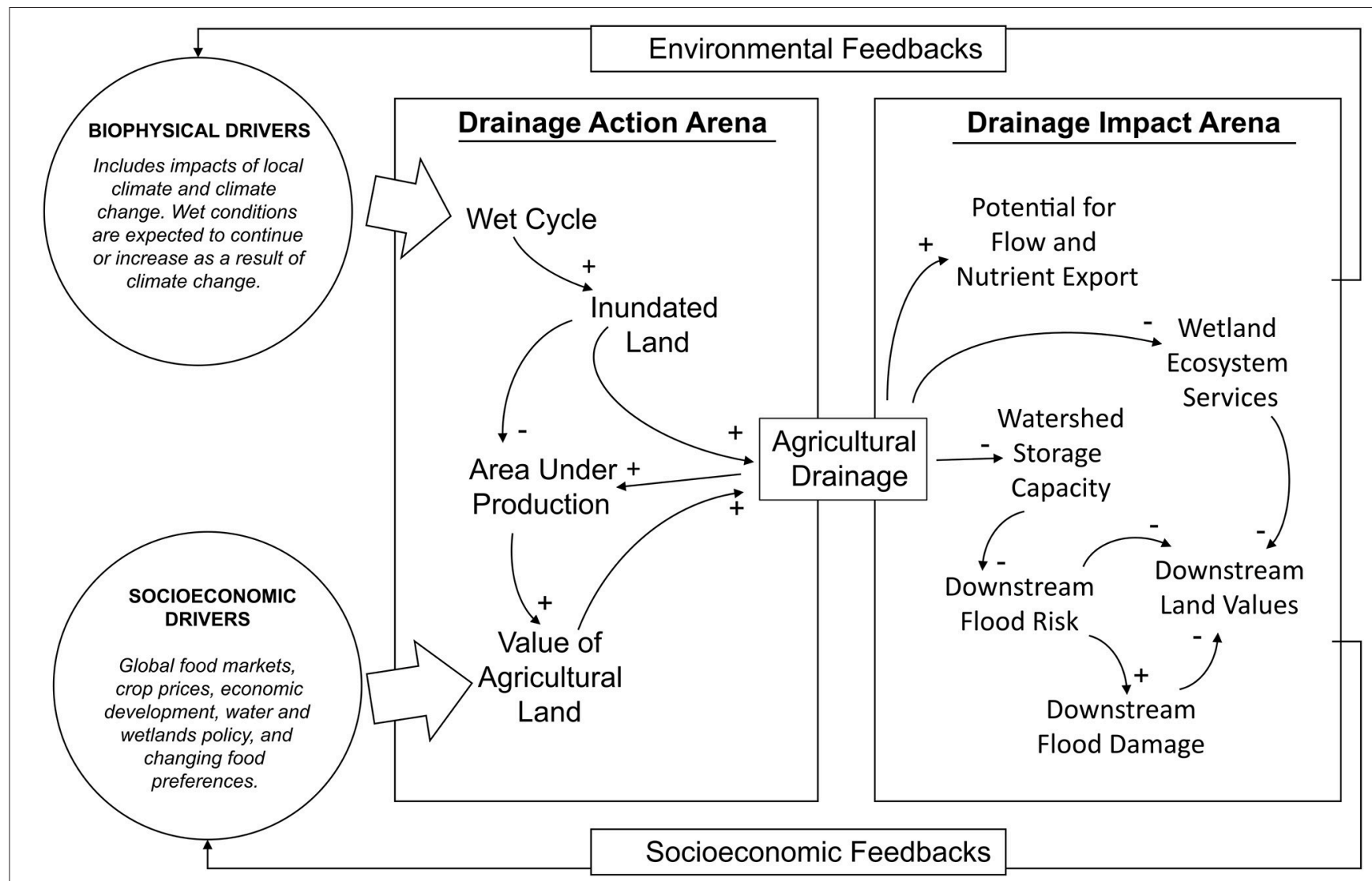

FIGURE 1 | Agricultural wetland drainage system interactions. The figure describes a decision-making arena, where benefits tend to be accrued, and the impact arena, which can be spatially and economically isolated from the decision-making arena (e.g., Pattison-Williams et al., 2018). The polarity of a relationship (+/-) indicates whether nodes have positive relationships (e.g., an increase in wet climatic conditions lead to an increase in the area of inundated land), or negative relationships (e.g., an increase in flood risk leads to a decrease in land values).

production, productive area, and land value; a practice resulting degradation of land production and value; a practice leading to the degradation of key ecosystems; or simply a negative impact analogous to pollution. Among agricultural producers, perspectives may vary depending on personal situations and values, as well as location within the watershed and whether drainage yields personal benefits, or costs, for example associated with increased flood risk. As such, conflict over drainage can be extreme, tapping into people's sense of identity and long-standing ideological standpoints-something clearly demonstrated by the situation in Quill Lakes, Saskatchewan where multiple, disparate perspectives have resulted in high levels of conflict (Mandryk, 2017).

\section{DRAINAGE IN SASKATCHEWAN}

As already noted, drainage in the Canadian Prairies has been essential to the region's dominant productivity in Canadian agriculture. Recently, the Province of Saskatchewan created a new approach to agricultural wetland drainage, driven by tensions among stakeholders and high profile issues such as flooding, water quality, and other environmental concerns. This new approach is codified in the 2015 Agricultural Water Management Strategy and related legislation, regulation, and policy under the control of the provincial Water Security Agency WSA; (Ferguson, 2018; Water Security Agency, 2018b). In 2016, Provincial Bill 44 amended the existing Water Security Agency Act, giving new authority to the government to remove drainage works and making it so that all drainage, existing or future, must be approved by the WSA, effectively making the majority of existing drainage in the province non-compliant (Government of Saskatchewan, 2016). Under the new regime, drainage must be managed through local level governance networks-groups of land and infrastructure owners and operators who are encouraged by the WSA to work together to coordinate and manage drainage into an adequate outlet (Water Security Agency, 2018a). Ostensibly, Saskatchewan's new approach is simple: "all drainage needs an approval" (Water Security Agency, 2018b). Networks are to work collaboratively with the guidance of a Qualified Person (i.e., a professional engineer, professional agrologist, technician, technologist, or other person assisting with drainage applications) to prepare an application and related permits (e.g., Aquatic Habitat Protection Permits; Water Security Agency, 2018b). 
The Province has drawn a clear line around drainage management, one focused on land and infrastructure owners and operators, and where the goal is to control the movement of water within a specific area. Unfortunately, this approach has isolated drainage from other related sectors. Perhaps most obviously, drainage is directly linked to general watershed management, as both are managed by the WSA, which is the hub for all water issues in Saskatchewan. Despite sharing an institution, presently there are no explicit links between drainage and other branches of water management. To be fair to the WSA, related policy development is ongoing and is expected to address the relationship between the Agricultural Water Management Strategy and other, related elements of water management. Currently drainage decisions are disconnected from the broader group of related actors and considerations, whether those are provincial watershed management plans or efforts (provincial and federal) to conserve wetland habitat in this key region for waterfowl (e.g., Prairie Habitat Joint Venture's Implementation Plan), despite the broader impact and interaction of drainage. Additionally, drainage is also intricately linked beyond water management to the agricultural sector and related economic development, as well as to environmental concerns and to climate change mitigation and adaptation. As with the above disconnect from water management, drainage has no explicit connection with these topics. Initiatives such as funding for agricultural Beneficial Management Practices (BMPs) can create links to drainage, but these are voluntary.

Research on best practices for natural resource governance offer suggestions for improving the fragmentation described above, for example actions like coordinating water policies and improving interplay among agencies (Bakker and Cook, 2011; de Loë, 2017). Still, these solutions are often presented within a water-centric frame, meaning that the hydrological dimensions of the system provide the de-facto boundaries for the policy sector, such as Integrated Water Resource Management (de Loë and Patterson, 2017). There are limits to a water-centric approach: where multiple policy sectors intersect at multiple scales, where the watershed scale fails to capture key actors, where the problem is symptomatic of larger issues, and where decisions and actions are made by actors outside the water sector we cannot assume a water-centric frame or approach would be sufficient (de Loë, 2017). Agricultural wetland drainage, where water may be an obvious focus, but where the surrounding context is not exclusively water-centric, is a clear example of where a more systemic approach is needed.

\section{WATER-CENTRIC GOVERNANCE FRAGMENTATION}

Given that an obvious element of drainage is the movement of water, discussing the management and governance of drainage within a water-centric frame would seem, at first glance, to be logical. While water resources in Saskatchewan are largely managed by the WSA, fragmentation exists between different branches within the WSA. There are few, if any, explicit links, or coordination between drainage, watershed management, and drinking water (e.g., source water protection), despite all three occurring and interacting within the same watersheds. There are no legal requirements, for example, for the WSA to follow the advice of advisory committees or to follow approved watershed management plans (Hurlbert, 2009).

The challenge with Saskatchewan's Agricultural Water Management Strategy is not so much what is included, but what is not. The structure is clear, but narrow. Applications are made by landowners or operators, as individuals or groups, with the help of a Qualified Person, and approved by the WSA. When it comes to applications, actors beyond the designated adequate outlet play no role in this process. So, while policies related to wetland loss, other water management, and other topics are under development, the application process itself is designed to limit interaction. Applicants themselves are pointed to the Farm Stewardship Program for funding around BMPs to help maintain or improve the quality of soil, water, air, and biodiversity (Water Security Agency, 2018b), but there are no explicit requirements or preferences for BMPs (e.g., green infrastructure) over gray infrastructure capable of retaining water through gated structures or other similar infrastructure. It is also unclear what, if any, role there is for conservation groups, water stewardship groups, agricultural associations, local governments, and others in drainage planning and decision making. So, despite the connection between wetland drainage, watershed management, and conservation, these links are not explicitly recognized in the regulatory process. The drainage approval process "informally considers" water quality and wetlands, but there are limited policies and no formal ties between these informal considerations and existing source water protection plans or watershed management plans (Ferguson, 2018).

This type of fragmentation is not unique to Saskatchewan. Few Canadian provinces have any watershed protection that links land use, water allocation, and water quality (Hurlbert, 2009). Indeed, fragmentation is a challenge for water governance internationally, in different regions, (e.g., driving Integrated Regional Water Management in California; Lubell and Lippert, 2011), but also globally, across national and regional borders (Pahl-Wostl et al., 2008). The typical lack of coordination of multiple actors, processes, or within and between institutions is a well-recognized and ubiquitous water problem (Bakker and Cook, 2011). This lack of coordination in governance and management is reflected across Canada in the separation of ground and surface water, drinking water, water quantity, and water quality, as well as in the differences in priority and authority between them (de Loë and Kreutzwiser, 2005; Wheater et al., 2013; Breen, 2018). We see this fragmentation occurring across jurisdictions, between local governments, between local and provincial, between provinces, between provincial and federal, and with the growing application of First Nations rights and title (Renzetti and Dupont, 2017). Such fragmentation is also seen in other natural resource areas as well, such as fisheries (Loring, 2016).

There are myriad challenges and issues that occur as a result of this fragmentation. Perhaps the most obvious in the case at hand is that within the existing management and 
governance structure for agricultural wetland drainage, the only obvious inroad to link water stewardship activities is through the Qualified Person, where stewardship group members act as Qualified Persons or where there is incidental overlap (e.g., a water stewardship group member is also a landowner or operator within a drainage network). Otherwise, drainage is effectively governed and managed completely separately from other aspects water.

Calls to address fragmentation in water management and governance through various approaches and innovations are common refrains, including the need to establish clear roles for all actors and to explicitly coordinate activities and policies (Bakker and Cook, 2011; Hurlbert, 2016; de Loë, 2017). Coordinated and collaborative approaches have been developed and applied in many other contexts, such as Integrated Water Resource Management or Integrated River Basin Management (Parkes et al., 2010; Cohen and Davidson, 2011); examples from the European Union illustrate what an overarching framework for guiding and coordinating water policies of 28 member countries might look like (de Loë, 2017). However, such approaches are predicated on the assumption that the issue or challenge at hand is in fact directly influenced by water-centric variables (e.g., flow, withdrawals). This may make sense where problems are well defined and where water actors have the mandate to address the challenge, but may be inappropriate where this is not the case (de Loë, 2017). While some attempts have been made to make water-centric analytical frameworks more holistic (e.g., Integrated Water Resource Management), these are still predicated on the watershed scale as the appropriate management scale (Parkes et al., 2010). With examples like that of drainage, where the agricultural, not hydrological system presents the critical drivers of change, approaching the discussion from a water lens, at a water scale is problematic, particularly as it is in high contrast to the food-centric perspectives of agricultural producers.

\section{CROSS-SECTOR FRAGMENTATION}

Drainage is an example of the complexity inherent to so many contemporary environmental management challenges: where key policy sectors intersect at multiple scales; where watercentric approaches (e.g., application of the watershed scale) fail to capture key actors and drivers; where the problem(s) are symptomatic of larger, broader issues within and outside the water sector; and, where it is actors outside the water sector that are making decisions and taking actions that shape what happens within the water sector (de Loë, 2017; de Loë and Patterson, 2017). Examples of such situations include drinking water on First Nations reserves, algal blooms in Lake Erie, sustainable water management within mining leases, and coordination over issues like climate change (Barrett, 2009; de Loë, 2017).

Multiple, key policy centers overlap (and conflict) around the issue of drainage; certainly water is at the fore, but agricultural, economic development, and conservation/endangered species policies also are at play. Presently, Saskatchewan's economic development plan aims for a 10 million ton increase in crop production by 2020 (Government of Saskatchewan, 2014), suggesting not only a strong influence of the agricultural sector over drainage, but a link between drainage and provincial economic growth. There are also links to climate change policy, with the provincial climate change strategy highlighting the need to enhance the adaptive capacity and resilience of the agricultural sector Government of Saskatchewan. However, there is little explicit recognition of the relationship between water instruments, including drainage, and climate change in Saskatchewan (Hurlbert, 2016).

Another piece for consideration is that is specific to drainage, but not necessarily specific to cases where different groups of people derive different ecosystem services from a shared landscape, is that while water may be the obvious resource being managed, often there is no targeted end user of the water that people are moving, or consideration for those downstream. In other words, drained water becomes a by-product, more analogous to pollution than to a resource for some stakeholders, while the resource is lost or altered for other water users (e.g., wildlife), at a cost to society as a whole. When it comes to agricultural wetland drainage, the fundamental ecosystem service being altered is the storage capacity within the watershed. This storage capacity affects the arable land area, most notably during wet periods, and this arable area is also a valuable resource (see Figure 1). Additionally drainage provokes questions and conversations related to conservation, habitat, and ecosystem services beyond storage capacity. In other words, while a watercentric frame generally proceeds from the assumption that water is an desired asset to all groups, the case of drainage illustrates that resource-centric framings, whether around water or fish or some other perceived good, impose analytical limitations. Multiple lenses, within frameworks for transdisciplinarity, may be preferable.

For all of the above, the actors and the scales they work at include, but extend beyond, the scale of the watershed and the resource of water. In particular, key actors are found within agriculture, as well as economic development. And within each of the examples above we see broader issues that encompass, but extend far beyond drainage and water. Based on this, agricultural wetland drainage may provide another example of a water challenge that warrants a broader, systemic, non- water-centric framing.

\section{DISCUSSION AND CONCLUSIONS}

If we consider drainage as it is currently managed, we can quickly identify it's isolation from surrounding systems (see Figure 2, Drainage Frame). In this frame drainage has been driven by agriculture, specifically benefits to producers. Under such a limited regulatory environment these economic benefits are decoupled from the costs of drainage to downstream landowners and society as a whole through flooding, degraded water quality, and impacts on biodiversity. Whereas if we consider drainage specifically within a water-centric frame, exploring its isolation 


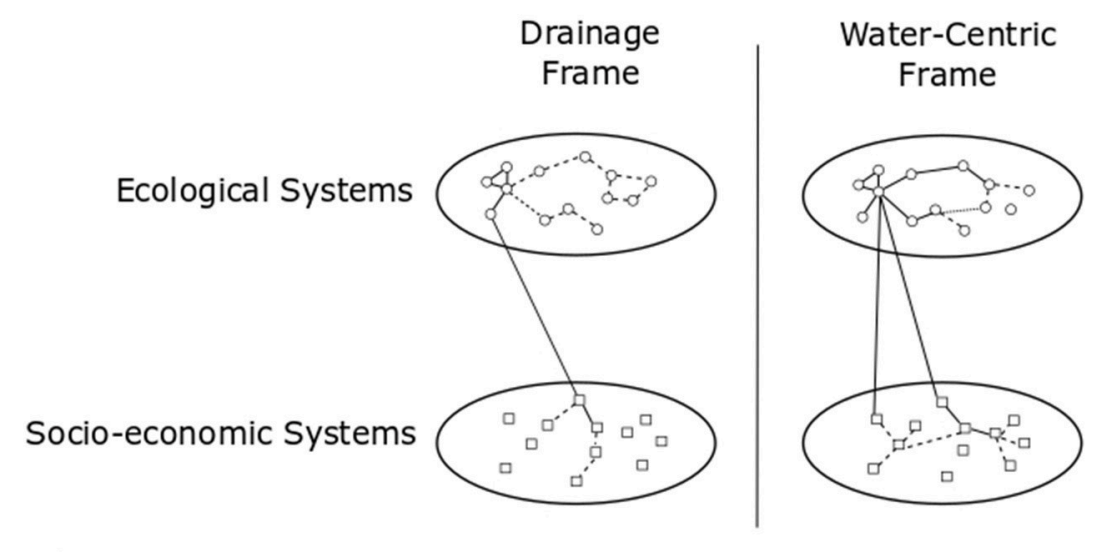

Socio-economic Systems

Drainage Subsystem

Conservation \& Recreation
Subsystem

Agricultural Subsystem

Punicipal Water Management
Ecological Systems

Hydrological Subsystem

$\sum_{0}$ Wetlands Subsystem

O. Source Water Quality Subsystem
Cross-Sector Network Frame

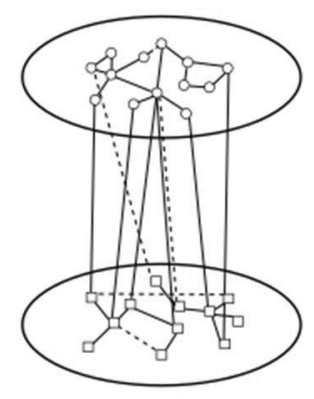

Linkages

Explicit Link

Implicit or Potential Link

FIGURE 2 | A schematic of drainage and other water issues as viewed through three frames. Schematic adapted from Bodin et al. (2016) with content based on a review of literature, professional knowledge, and qualitative data collection. In the current, drainage frame, connections to all aspects of the ecosystem are limited or implicit, and there is little connection of drainage to other socio-economic systems such as conservation and municipal water. A water-centric frame improves the integration of issues, but is centerd around the hydrological system and connections to related areas become less explicit as you radiate out from this center. A cross-sector network frame actively seeks out appropriate connections across sectors and subsystems.

from other branches of water management and from other jurisdictions, the addition of explicit coordinating water policies could potentially address fragmentation, building connections between the management of the watershed generally and the management of drainage (see Figure 2, Water-Centric Frame). A water-centric approach allows for collaboration and coordination on issues, but driven from a specific water lens and scale. However, if we consider drainage within a non-water-centric, cross-sector network frame, such as those discussed above, such coordinating water policies would be, "necessary, but not sufficient" (de Loë, 2017).

Recently, network-based approaches have emerged for understanding social-ecological systems and designing governance that "fits" current socio-economic and ecological circumstances of each system and that facilitates effective interplay among the socio-economic sectors and institutions involved (Epstein et al., 2015; Barnes et al., 2017). The premise is that decision makers can be linked to each other directly, through formal interactions (i.e., the socio-economic subsystems in Figure 2), and indirectly, through connections to shared resources; likewise, people are directly, and indirectly linked to various ecosystem components through their actions and the cascading impacts of their actions. The resultant social-ecological networks can facilitate or hinder effective problem solving depending on the degree to which networks among actors facilitate collaboration and knowledge sharing across the many involved socio-economic and ecosystem subsystems (Barnes et al., 2017).

So, how then can we proceed in designing governance that "fits" the socio-economic and ecological circumstances, working to address the gaps in current management and governance of drainage? Systemic approaches are challenging, particularly from a governance perspective (de Loë and Patterson, 2017). Multiple alternative frameworks exist from different disciplines that provide cross-sector linkages, allow for porous boundaries between subsystems, and apply an adaptive approach (see Figure 2, Cross-Sector Frame). For example, the developmentfocused New Regionalism literature presents an integrated, multi-level framework, with a focus on working with multiple, overlapping and conflicting regions (Wheeler, 2002). Examples of where New Regionalism frameworks have been applied to water exist, but while they are capable of accounting for multiple actors and addressing both economic development and environmental aspects, there are few examples that incorporate ecosystem services (Peterson et al., 2007; Breen, 2018). Another example is the Social-Ecological Systems Framework (SESF) framework 
developed by Ostrom (2009), which offers a more systemic approach. Ostrom's original framework has since been refined to include ecological rules, as well as social, economic, and political settings (Epstein et al., 2013) with a goal of providing an inclusive and integrated point from which to consider the interactions of multiple actors and processes (Brock and Carpenter, 2007; de Loë, 2017). However, the complexities of drainage, particularly related to the aforementioned role of water as a by-product, as opposed to the storage capacity of the watershed, makes it challenging to slot drainage within the SESF, given the latter's construction around specific common pool resources. Revisions to the SESF may reframe the conversation from resource systems to ecosystem service provisioning systems. In Saskatchewan, for example, an approach that integrates various elements of both the socio-economic and ecological systems has a much higher chance of producing a wider range of long-term positive outcomes for multiple sectors.

Ongoing recognition of cross-sector connections will continue to increase the number and variety of actors involved in governance and management of water. As a result, the need to connect these actors within the socio-economic system, as well as with the ecological system increases. But while the need increases, change within the governance system, and the dominant institutions is limited. The increase in the number of actors and complexity of networks has come with little to no change to the hierarchical and fragmented nature of higher level governments who continue to hold the decision making power (Bakker and Cook, 2011; de Loë, 2017). True

\section{REFERENCES}

Agriculture and Agri-Food Canada (2016). An Overview of the Canadian Agriculture and Agri-Food System 2016. Ottawa. Avaialble online at: http://www.agr.gc.ca/eng/about-us/publications/economic-publications/ an-overview-of-the-canadian-agriculture-and-agri-food-system-2016/?id= 1462288050282

Backeberg, G. R., and Sanewe, A. J. (2006). The research and development strategy for water utilisation in agriculture-responding to diverse needs of farmers in South Africa. Irrigat. Drain. 55, 281-290. doi: 10.1002/ird.232

Bakker, K., and Cook, C. (2011). Water governance in Canada: innovation and fragmentation. Int. J. Water Res. Develop. 27, 275-289. doi: $10.1080 / 07900627.2011 .564969$

Barnes, M. L., Bodin, Ö., Guerrero, A. M., McAllister, R. J., Alexander, S. M., and Robins, G. (2017). The social structural foundations of adaptation and transformation in social-ecological systems. Ecol. Soc. 22:16. doi: $10.2139 /$ ssrn.2932575

Barrett, D. J. (2009). Thinking outside the lease - towards a strategic view of regional water management by the mining industry. Mining Technol. 118, 131-141. doi: 10.1179/174328610X12682159814867

Bartzen, B. A., Dufour, K. W., Clark, R. G., and Caswell, F. D. (2010). Trends in agricultural impact and recovery of wetlands in prairie Canada. Ecol. Appl. 20, 525-538. doi: 10.1890/08-1650.1

Beck, M. B., and Villarroel Walker, R. (2013). On water security, sustainability, and the water-food-energy-climate nexus. Front. Environ. Sci. Eng. 7, 626-639. doi: 10.1007/s11783-013-0548-6

Blann, K. L., Anderson, J. L., Sands, G. R., and Vondracek, B. (2009). Effects of agricultural drainage on aquatic ecosystems: a review. Crit. Rev. Environ. Sci. Technol. 39, 909-1001. doi: 10.1080/10643380801977966

Bodin, Ö., Robins, G., McAllister, R. R. J., Guerrero, A. M., Crona, B., Teng,ö, M., et al. (2016). Theorizing benefits and constraints in collaborative environmental polycentric governance-where there are multiple independent, but interacting decision making centers-can be undercut by such hierarchical structure and ongoing power imbalance (Carlisle and Gruby, 2017; de Loë, 2017). While this approach to governance remains, so too does fragmentation, leaving drainage, -and other examples of water related conflicts-isolated, both from other aspects of water management, as well as from broader contextual connections.

\section{AUTHOR CONTRIBUTIONS}

All three authors contributed to the writing of this article and design of figures. PL and $\mathrm{HB}$ are the Principle Investigators of the overarching project into which this article fits. S-PB is a post-doctoral fellow, and was the lead author of this article.

\section{FUNDING}

The research published in this paper is part of the project titled Prairie Drainage Governance funded by the Global Water Futures program, Canada First Research Excellence Fund. Additional information is available at www.globalwaterfutures.ca.

\section{ACKNOWLEDGMENTS}

We would like to thank Merrin Macrae, Bob Clark, and the two reviewers for their review and helpful suggestions. governance: a transdisciplinary social-ecological network approach for empirical investigations. Ecol. Soc. 21:40. doi: 10.5751/ES-08368-210140

Breen, S.-P. (2018). Exploring a new regionalism based approach to managing drinking water systems in rural regions. Soc. Nat. Res. 31, 917-976. doi: 10.1080/08941920.2017.1423432

Brock, W. A., and Carpenter, S. R. (2007). Panaceas and diversification of environmental policy. Proc. Nat. Acad. Sci. U.S.A. 104, 15206-15211. doi: 10.1073/pnas.0702096104

Carlisle, K., and Gruby, R. L. (2017). Polycentric systems of governance: a theoretical model for the commons. Policy Stud. J, 1-26. doi: 10.1111/psj.12212

Cohen, A., and Davidson, S. (2011). The watershed approach: challenges, antecedents, and the transition from technical tool to governance unit. Water Alternat. 4, 1-14.

Cortus, B. G., Jeffrey, S. R., Unterschultz, J. R., and Boxall, P. C. (2011). The economics of wetland drainage and retention in saskatchewan. Can. J. Agricul. Econ. 59, 109-126. doi: 10.1111/j.1744-7976.2010.01193.x

Cox, M. (2014). Applying a social-ecological system framework to the study of the taos valley irrigation system. Hum. Ecol. 42, 311-324 doi: 10.1007/s10745-014-9651-y

de Loë, R. (2017). "Coordinating water policies: necessary, but not sufficient," in Water Policy and Governance in Canada, eds S. Renzetti and D. Dupont (Basel: Springer International Publishing), 231-248.

de Loë, R., and Kreutzwiser, R. (2005). Closing the groundwater protection implementation gap. Geoforum 36, 241-256. doi: 10.1016/j.geoforum.2003.09.007

de Loë, R., and Patterson, J. (2017). Rethinking water governance: moving beyond water-centric perspectives in a connected and changing world. Nat. Res. 57, 75-100. Available online at: https://www.jstor.org/stable/26202188?seq=1\# metadata_info_tab_contents

Dumanski, S., Pomeroy, J. W., and Westbrook, C. J. (2015). Hydrological regime changes in a Canadian Prairie basin: hydrological regime changes in 
a Canadian Prairie basin. Hydrol. Process. 29, 3893-3904. doi: 10.1002/hyp. 10567

Epstein, G., Pittman, J., Alexander, S. M., Berdej, S., Dyck, T., Kreitmair, U., et al. (2015). Institutional fit and the sustainability of social-ecological systems. Curr. Opin. Environ. Sustain. 14, 34-40. doi: 10.1016/j.cosust.2015.03.005

Epstein, G., Vogt, J. M., Mincey, S. K., Cox, M., and Fischer, B. (2013). Missing ecology: integrating ecological perspectives with the social-ecological system framework. Int. J. Commons 7, 432-453. doi: 10.18352/ijc.371

European Environment Agency (2018). European Waters: Assessment of Status and Pressures 2018. EEA Report No. 7. Luxembourg.

Ferguson, J. (2018). 2018 Report - Volume 1: Report of the Provincial Auditor to the Legislative Assembly of Saskatchewan. Regina.

Government of Saskatchewan (2014). Saskatchewan Plan for Growth - 2020 and Beyond. Available online at: https://www.saskatchewan.ca/government/ budget-planning-and-reporting/plan-for-growth

Government of Saskatchewan (2016). The Water Security Agency Amendment Act, Pub. L. No. 44.

Government of Saskatchewan (2017). Prairie Resilience: A Made-in-Saskatchewan Climate Change Strategy. Available online at: http://publications.gov.sk.ca/ documents/66/104890-2017ClimateChangeStrategy.pdf

Hurlbert, M. (2009). Comparative water governance in the four western provinces. Prairie Forum 34, 45-77.

Hurlbert, M. (2016). "Water governance in the prairie provinces," in Vulnerability and Adaptation: The Canadian Prairies and South America, eds H. Diaz, M. Hurlbert, and J. Warren (Calgary, AB: University of Calgary Press), 217-247.

Loring, P. A. (2016). The political ecology of gear bans in two fisheries: Florida's net ban and Alaska's Salmon wars. Fish Fish 18, 94-104. doi: 10.1111/faf.12169

Loring, P. A., Gerlach, S. C., and Huntington, H. P. (2013). The new environmental security: linking food, water, and energy for integrative and diagnostic social-ecological research. J. Agricul. Food Syst. Communit. Dev. 3, 55-61. doi: $10.5304 /$ jafscd.2013.034.005

Lubell, M., and Lippert, L. (2011). Integrated regional water management: a study of collaboration or water politics-as-usual in California, USA. Int. Rev. Adm. Sci. 77, 76-100. doi: 10.1177/0020852310388367

Mandryk, M. (2017). March 11. Drainage Woes Plague Province. Regina: Regina Leader-Post. Avaialble online at: https://leaderpost.com/business/ agriculture/drainage-woes-plague-province

Ostrom, E. (2009). A general framework for analyzing sustainability of social-ecological systems. Science 325, 419-22. doi: 10.1126/science. 1172133

Pahl-Wostl, C., Gupta, J., and Petry, D. (2008). Governance and the global water system: a theoretical exploration. Glob. Governan. 14, 419-435.

Parkes, M. W., Morrison, K. E., Bunch, M. J., Hallstro, L. K., Neudoerffer, R. C., Venema, H. D., et al. (2010). Towards integrated governance for water, health and social - ecological systems: the watershed governance prism. Glob. Environ. Change 20, 693-704. doi: 10.1016/j.gloenvcha.2010.06.001
Pattison-Williams, J. K., Pomeroy, J. W., Badiou, P., and Gabor, S. (2018). Wetlands, flood control and ecosystem services in the Smith Creek Drainage Basin: a case study in Saskatchewan, Canada. Ecol. Econ. 147, 36-47. doi: 10.1016/j.ecolecon.2017.12.026

Peterson, A., Mcalpine, C. A., Ward, D., and Rayner, S. (2007). New regionalism and nature conservation: lessons from South East Queensland, Australia. Landsc. Urban Plan. 82, 132-144. doi: 10.1016/j.landurbplan.2007.02.003

Renzetti, S., and Dupont, D. P. (eds.) (2017). Water Policy and Governance in Canada. Vol. 17. Basel: Springer.

Rittel, H., and Webber, M. M. (1973). 2.3 planning problems are wicked. Polity 4, 155-169.

Schindler, D. W. (2001). The cumulative effects of climate warming and other human stresses on Canadian freshwaters in the new millennium. Can. J. Fish. Aquat. Sci. 58, 283-296. doi: 10.1139/f00-179

United Nations, (2003). The Right to Water. Available online at: http://www.un. org/waterforlifedecade/human_right_to_water.shtml

Water Security Agency (2018b). What is the New Agricultural Water Management Strategy? Available online at: https://www.wsask.ca/Water-Programs/ Agricultural-Drainage-/Agricultural-Water-Management-Strategy/ (Accessed June 11, 2018).

Water Security Agency (2016). What is Drainage? (No. Fs-319). Moose Jaw, SK.

Water Security Agency (2018a). Qualified Persons. Available online at: https:// www.wsask.ca/Water-Programs/Agricultural-Drainage-/Qualified-Persons/ (Accessed June 11, 2018)

Weber, M., and Cutlac, M. (2017). "Agricultural and water in canada - challenges and reform for the $21 \mathrm{C}$," in Water Policy and Governance in Canada, eds S. Renzetti and D. Dupont (Basel: Springer International Publishing), 395-416.

Wheater, H., Bennett, E., de Loë, R., Friesen, R., Hamilton, K. E., Hepworth, L., et al. (2013). Water and Agriculture in Canada: Towards Sustainable Management of Water Resources. The Expert Panel on Sustainable Management of Water in the Agricultural Landscapes of Canada. Ottawa, ON: Council of Canadian Academies.

Wheeler, S. (2002). The new regionalism: key characteristics of an emerging movement. J. Am. Plan. Assoc. 68, 267-278. doi: 10.1080/019443602089 76272

Conflict of Interest Statement: The authors declare that the research was conducted in the absence of any commercial or financial relationships that could be construed as a potential conflict of interest.

Copyright (C) 2018 Breen, Loring and Baulch. This is an open-access article distributed under the terms of the Creative Commons Attribution License (CC BY). The use, distribution or reproduction in other forums is permitted, provided the original author(s) and the copyright owner(s) are credited and that the original publication in this journal is cited, in accordance with accepted academic practice. No use, distribution or reproduction is permitted which does not comply with these terms. 